\title{
Suplementasi Dedak Padi pada Pakan Berbasis Limbah Pertanian terhadap Performa Sapi Peranakan Ongole: Studi Kasus di Kelompok Ternak Kota Probolinggo
}

\author{
(Supplementation of Rice Bran at Feed Based on Agricultural Byproduct \\ on Ongole Cross Cattle: A Case Study of Farmer Group \\ in Probolinggo City)
}

Anggraeny YN, Sukmasari PK, Mariyono

Loka Penelitian Sapi Potong, Jl. Pahlawan No. 2, Grati, Pasuruan, Jawa Timur

yennysahim@gmail.com

\begin{abstract}
The use of food crop waste as beef cattle feed requires supplementation of protein source or energy source so that can be utilized optimally by livestock. The aim of this study was to determine the effect of rice bran supplementation on nutrient consumption (DM, OM, CP, CF and TDN), daily weight gain (ADG) and blood profile (glucose and blood urea) on PO heifer. This research was conducted in Jaya Abadi and Progo Jaya farmer groups at the city of Probolinggo. The research materials consisted of 21 of PO heifers in Jaya Abadi and 21 of PO heifer in Progo Jaya. Parameters were ADG, nutrient consumption and blood profile of livestock in each group before and after supplementation of rice bran. Supplementation of rice bran increased ADG of cow both in Jaya Abadi Group $(0.15 \pm 0.06 \mathrm{~kg} / \mathrm{head} /$ day vs $0.25 \pm 0.33 \mathrm{~kg} / \mathrm{head} / \mathrm{day})$ and in Progo Jaya group $(0.25 \pm 0.33 \mathrm{~kg} / \mathrm{head} /$ day vs $0.38 \pm 0.81 \mathrm{~kg} / \mathrm{head} /$ day $)$. Supplementation of rice bran increased blood glucose level of a beef cow in both Jaya Abadi $(19.88 \mathrm{mg} / \mathrm{dl}$ vs. $22.36 \mathrm{mg} / \mathrm{dl})$ and Progo Jaya $(20.97 \mathrm{mg} / \mathrm{dl}$ vs. $23.55 \mathrm{mg} / \mathrm{dl})$. Rice bran supplementation on feed based on food crop byproduct that applied in beef cow increased its biological value by increasing the content of crude protein, energy content in the form of TDN, average daily gain and blood glucose.
\end{abstract}

Key Words: Supplementation, Beef Cow, Agricultural Byproduct, Blood Glucose, Blood Urea

\begin{abstract}
ABSTRAK
Penggunaan limbah tanaman pangan sebagai pakan sapi potong memerlukan suplementasi sumber protein atau sumber energi agar bisa dimanfaatkan secara optimal oleh ternak. Penelitian ini bertujuan untuk mengetahui pengaruh suplementasi dedak padi pada sapi PO calon induk terhadap konsumsi nutrien (BK, BO, PK, SK dan TDN), pertambahan berat badan harian (PBBH) dan profil darah (glukosa dan urea darah). Penelitian ini dilakukan di kelompok ternak Jaya Abadi dan Progo Jaya di Kota Probolinggo. Materi penelitian berupa 21 ekor sapi di kelompok Jaya Abadi dan 21 ekor sapi di kelompok Progo Jaya. Parameter yang diukur adalah PBBH, konsumsi nutrien dan profil darah pada ternak sebelum dan sesudah dilakukan suplementasi dedak padi. Suplementasi dedak padi mampu meningkatkan PBBH sapi calon induk di kelompok Jaya Abadi $(0,15 \pm 0,06$ vs $0,25 \pm 0,33 \mathrm{~kg} / \mathrm{ekor} / \mathrm{hari})$ maupun di kelompok Progo Jaya $(0,25 \pm 0,33$ vs $0,38 \pm 0,81$ $\mathrm{kg} / \mathrm{ekor} / \mathrm{hari})$. Suplementasi dedak padi mampu meningkatkan kadar glukosa darah sapi calon induk di kelompok Jaya Abadi (19,88 vs 22,36 mg/dl) maupun di kelompok Progo jaya (20,97 vs $23,55 \mathrm{mg} / \mathrm{dl}$ ). Disimpulkan suplementasi dedak padi pada sapi induk dengan pakan berbasis limbah tanaman pangan dapat meningkatkan nilai biologis pakan karena dapat meningkatkan kandungan protein kasar, meningkatkan energi dalam bentuk TDN, PBBH dan glukosa darah.
\end{abstract}

Kata Kunci: Suplementasi, Sapi Induk, Limbah Pertanian, Glukosa Darah, Urea Darah 


\section{PENDAHULUAN}

Selain rumput lapangan dan hijauan pakan yang dibudidayakan, masih ada hijauan lain yang dapat digunakan sebagai sumber pakan yaitu limbah pertanian. (Martawidjaya 2003). Jerami padi, jerami jagung dan limbah ubi kayu merupakan limbah pertanian yang paling banyak dihasilkan karena tanaman tersebut mempunyai luas panen tertinggi (Utomo 2004; Umiyasih \& Wina 2008; Anonimous 2010).

Pakan yang berasal dari limbah pertanian dan perkebunan mempunyai keterbatasan karena mengandung protein kasar dan bahan organik terlarut yang rendah serta serat kasar yang tinggi (Preston \& Leng 1987) sehingga diperlukan perlakuan untuk peningkatan kecernaan serat atau suplementasi supaya mampu mendukung produktivitas ternak ruminansia (Preston \& Leng 1987; Utomo 2004).

Suplementasi bahan pakan sumber energi sangat bermanfaat bagi sapi induk yang diberi pakan hijauan daerah tropis maupun hijauan berbasis limbah pertanian karena hijauan tersebut mempunyai kandungan energi rendah. Sapi induk memerlukan pakan dengan energi tersedia dalam bentuk glukosa yang cukup karena energi merupakan nutrisi primer untuk tercapainya performa reproduksi optimal (Mass 1987). Intake energi yang tinggi akan mempercepat pubertas pada sapi dara (Schillo et al. 1992), memperpendek masa anoestrus post partus, meningkatkan angka konsepsi dan kebuntingan. Ketidakseimbangan kandungan energi dan protein pada peningkatan kandungan protein kasar pada pakan diduga menjadi penyebab menurunnya fertilitas pada sapi induk (Sinclair et al. 2000). Chooke et al. (2007) melaporkan bahwa suplementasi sumber energi akan meningkatkan kadar glukosa darah.

Dedak padi merupakan bahan pakan ternak yang merupakan hasil ikutan dari industri penggilingan gabah untuk menghasilkan beras. Menurut Hartadi et al. (1997) terdapat tiga macam dedak berdasarkan kandungan serat kasarnya. Menurut Hartadi (1997) dedak padi mengandung serat kasar 17,67\%; PK 9,9\% dan TDN 57,4\%; sedangkan hasil analisa Laboratorium Nutrisi Loka Penelitian Sapi Potong (2015) kandungan PK dan TDN dedak padi berturut-turut adalah 9,36\% dan 59,9\%. Penelitian ini bertujuan untuk mengetahui pengaruh suplementasi dedak padi terhadap konsumsi nutrien, pertambahan berat badan harian $(\mathrm{PBBH})$ dan profil darah sapi PO induk.

\section{MATERI DAN METODE}

Penelitian ini dilakukan di dua kelompok peternak di Kota Probolinggo yaitu kelompok ternak Jaya Abadi dan kelompok ternak Progo Jaya. Materi penelitian berupa 21 ekor sapi PO induk tidak bunting di kelompok ternak Jaya Abadi dan 21 ekor sapi PO induk tidak bunting di kelompok ternak Progo Jaya dan pakan berbasis limbah jagung, daun rambanan dan dedak padi. Sapi dipelihara pada kandang individu. Penelitian dilakukan selama 100 hari yaitu 50 hari sapi induk diberi pakan sesuai pola peternak dan 50 hari berikutnya sapi induk diberi pakan sesuai pola peternak ditambahkan suplementasi berupa dedak padi. Pengamatan terhadap jumlah pakan pemberian dan pakan sisa serta jenis pakan dilakukan pada saat sebelum dilakukan suplementasi maupun pada saat sedang dilakukan suplementasi. Pengamatan dilakukan selama tiga hari berturut setiap dua minggu. Pengambilan sampel darah dilakukan sebelum dan sesudah dilakukan suplementasi. Darah diambil dari vena jugularis 4 jam sesudah sapi diberi pakan menggunakan tabung venoject setelah itu dilakukan sentrifugasi untuk pengambilan plasma darah selanjutnya dilakukan analisis glukosa dan urea plasma darah di Klinik Sejahtera Pasuruan. Kandungan nutrien bahan pakan dianalisis proksimat lengkap di 
Laboratorium Nutrisi Loka Penelitian Sapi Potong. Kandungan nutrisi bahan pakan ditampilkan pada Tabel 1.

Tabel 1. Kandungan nutrien bahan pakan

\begin{tabular}{lccccc}
\hline \multirow{2}{*}{ Jenis pakan } & \multirow{2}{*}{$\mathrm{BK}(\%)$} & \multicolumn{4}{c}{ Berdasar \% BK } \\
\cline { 3 - 6 } & & BO $(\%)$ & PK $(\%)$ & SK $(\%)$ & TDN $(\%)$ \\
\hline Rumput lapang & 22,54 & 83,14 & 7,72 & 24,64 & 54,99 \\
Rumput gajah & 13,45 & 85,41 & 7,98 & 29,26 & 49,61 \\
Jerami padi & 49,52 & 75,57 & 5,44 & 33,65 & 43,43 \\
Daun jagung kering & 84,70 & 85,47 & 7,28 & 22,31 & 50,26 \\
Klobot jagung kering & 69,74 & 94,96 & 3,25 & 27,66 & 47,18 \\
Jerami jagung segar & 31,37 & 95,73 & 8,97 & 21,19 & 42,48 \\
Daun rambanan & 25,00 & 91,60 & 25,70 & 13,30 & 76,00 \\
Dedak padi & 91,72 & 87,08 & 9,36 & 17,64 & 59,69 \\
\hline
\end{tabular}

Sumber: Laboratorium Nutrisi Loka Penelitian Sapi Potong (2015)

Parameter yang diamati adalah konsumsi nutrien (BK, BO, PK, SK dan TDN), profil darah (glukosa dan plasma urea darah) dan pertambahan berat badan harian. Data dianalisis secara deskriptif.

\section{HASIL DAN PEMBAHASAN}

\section{Profil pakan sebelum dilakukan suplementasi dedak padi}

Jenis pakan, jumlah responden pengguna jenis pakan, jumlah dalam ransum sebelum dilakukan suplementasi dicantumkan pada Tabel 2. Peternak di kelompok Jaya Abadi menggunakan jenis pakan lebih beragam dibandingkan peternak di kelompok Progo Jaya. Penggunaan bahan pakan yang beragam akan menyebabkan efek suplementasi karena kekurangan suatu nutrisi dari suatu bahan pakan akan dilengkapi dari bahan yang lain (Mcdonald 2010). Peternak di kelompok ternak Jaya Abadi menggunakan rumput, limbah pertanian maupun daun rambanan sebagai pakan ternak. Rumput alam dan rumput gajah diberikan sebanyak $\pm 39,75 \%$. Limbah pertanian jagung lebih banyak digunakan di kelompok ternak Jaya Abadi yaitu sebanyak $\pm 36,13 \%$ dan jerami padi hanya digunakan sebesar $\pm 10,90 \%$.

Tidak semua peternak di kelompok Progo Jaya menggunakan rumput lapang dan rumput gajah. Limbah pertanian yang digunakan hanya daun jerami kering dan klobot jagung kering. Rumput alam dan rumput gajah diberikan sebanyak $\pm 14,22 \%$. Limbah pertanian jagung yang digunakan sebanyak $\pm 85,77 \%$. Hal ini disebabkan peternak di Kelompok Progo Jaya sedikit yang melakukan penanaman rumput sebagai pakan ternak karena keterbatasan lahan untuk penanaman hijauan pakan ternak akibat alih fungsi lahan pertanian menjadi pemukiman penduduk (Utomo 2004; Simatupang \& Hadi 2004). 
Tabel 2. Jenis pakan, jumlah responden pengguna jenis pakan dan jumlah jenis pakan dalam ransum sebelum dilakukan suplementasi

\begin{tabular}{lcccccc}
\hline \multirow{2}{*}{ Jenis pakan } & \multicolumn{2}{c}{ Jumlah responden pengguna $(\%)$} & \multicolumn{2}{c}{ Jumlah dalam ransum $(\mathrm{kg})$} & \multicolumn{2}{c}{$\%$ dalam ransum } \\
\cline { 2 - 6 } & Jaya Abadi & Progo Jaya & Jaya Abadi & Progo Jaya & Jaya Abadi & Progo Jaya \\
\hline Rumput lapang & 100,00 & 23,81 & $11,82 \pm 4,38$ & $4,92 \pm 9,29$ & $18,72 \pm 3,29$ & $8,33 \pm 16,07$ \\
Rumput gajah & 95,24 & 14,28 & $13,38 \pm 5,72$ & $4,28 \pm 10,87$ & $21,05 \pm 7,16$ & $5,89 \pm 14,54$ \\
Jerami padi & 90,48 & 0 & $6,85 \pm 3,24$ & 0 & $10,90 \pm 4,39$ & 0 \\
Daun jagung kering & 85,71 & $90,48 \%$ & $10,22 \pm 7,33$ & $25,98 \pm 9,24$ & $14,91 \pm 7,14$ & $71,00 \pm 33,62$ \\
Klobot jagung kering & 95,24 & $38,09 \%$ & $6,67 \pm 4,07$ & $6,42 \pm 8,96$ & $10,42 \pm 5,30$ & $14,77 \pm 24,35$ \\
Jerami jagung segar & 61,90 & 0 & $6,90 \pm 7,90$ & 0 & $10,80 \pm 10,17$ & 0 \\
Daun rambanan & 76,19 & 0 & $8,70 \pm 6,30$ & 0 & $13,19 \pm 8,51$ & 0 \\
\hline
\end{tabular}




\section{Profil pakan saat dilakukan suplementasi dedak padi}

Jenis pakan, jumlah responden pengguna jenis pakan, jumlah dalam ransum saat dilakukan suplementasi dicantumkan pada Tabel 3.

Tabel 3. Jenis pakan, jumlah responden pengguna jenis pakan dan jumlah jenis pakan dalam ransum saat dilakukan suplementasi

\begin{tabular}{lcccccc}
\hline & \multicolumn{2}{c}{$\begin{array}{c}\text { Jumlah responden } \\
\text { pengguna }(\%)\end{array}$} & \multicolumn{2}{c}{$\begin{array}{c}\text { Jumlah dalam ransum } \\
(\mathrm{kg})\end{array}$} & \multicolumn{2}{c}{$\%$ dalam ransum } \\
\cline { 2 - 7 } Jenis pakan & $\begin{array}{c}\text { Jaya } \\
\text { Abadi }\end{array}$ & $\begin{array}{c}\text { Progo } \\
\text { Jaya }\end{array}$ & Jaya Abadi & Progo Jaya & Jaya Abadi & Progo Jaya \\
\hline Rumput & 100,00 & 28,57 & $11,98 \pm 6,14$ & $6,67 \pm 10,99$ & $22,66 \pm 5,05$ & $13,09 \pm 24,63$ \\
lapangan & & & & & & \\
Rumput gajah & 100,00 & 19,05 & $14,72 \pm 8,10$ & $5,24 \pm 11,05$ & $27,15 \pm 3,67$ & $27,04 \pm 15,38$ \\
Jerami padi & 0,00 & 0,00 & 0 & 0 & 0 & 0 \\
$\begin{array}{l}\text { Daun jagung } \\
\text { kering }\end{array}$ & 0,00 & 99,47 & 0 & $29,40 \pm 9,99$ & 0 & $68,97 \pm 31,07$ \\
$\begin{array}{l}\text { Kulit jagung } \\
\text { kering }\end{array}$ & 0,00 & 19,04 & 0 & $2,74 \pm 6,12$ & 0 & $5,32 \pm 12,48$ \\
$\begin{array}{l}\text { Jerami jagung } \\
\text { segar }\end{array}$ & 95,24 & 0,00 & $14,17 \pm 8,29$ & 0 & $26,06 \pm 8,42$ & 0 \\
$\begin{array}{l}\text { Daun } \\
\text { rambanan }\end{array}$ & 100,00 & 0,00 & $9,29 \pm 1,79$ & 0 & $20,00 \pm 7,80$ & 0 \\
Dedak padi & 100,00 & 100,00 & $1,58 \pm 0,76$ & $2,22 \pm 0,28$ & $2,98 \pm 0,32$ & $5,38 \pm 1,74$ \\
\hline
\end{tabular}

Peternak di kelompok ternak Jaya Abadi menggunakan rumput lapang, rumput gajah, jerami jagung segar, daun rambanan dan dedak padi. Rumput alam dan rumput gajah diberikan sebanyak $\pm 49,81 \%$. Limbah pertanian yang digunakan berupa jerami jagung segar yaitu 26,06\%. Hal ini disebabkan pada saat pengamatan sudah mulai dilakukan pemanenan jagung. Peternak di kelompok Jaya Abadi selalu menggunakan daun rambanan. Selama pemberian suplementasi dedak padi, daun rambanan diberikan sebanyak $20 \%$.

Peternak di kelompok Progo Jaya hanya menggunakan rumput lapang, rumput gajah, daun jagung kering, kulit jagung dan dedak padi. Sebagian besar peternak menggunakan daun jagung kering sebagai pakan sumber serat tunggal pada saat dilakukan suplementasi. Sebagian besar peternak di kelompok Progo Jaya telah melakukan upaya pengawetan pakan dalam bentuk kering. Daun jagung kering dan kulit buah jagung atau klobot ditempatkan di para para pada atap kandang. Sehingga dapat dikatakan bahwa peternak di kelompok Jaya Abadi dan Progo Jaya telah melakukan integrasi sapi potong dengan tanaman jagung terutama untuk memenuhi kebutuhan hijauan pakan ternak. Hal ini untuk mengatasi keterbatasan lahan hijauan pakan ternak pada sentra peternakan sapi potong (Anonimous 2007). Kota Probolinggo merupakan sentra tanaman jagung dengan penanaman jagung 2 kali setahun (BPS Kota Probolinggo 2015).

\section{Konsumsi nutrien sapi PO induk sebelum dan saat dilakukan suplementasi}

Konsumsi nutrien sapi induk pada sebelum dan saat dilakukan suplementasi dicantumkan pada Tabel 4. 
Tabel 4. Konsumsi nutrien sapi induk pada sebelum dan saat dilakukan suplementasi

\begin{tabular}{lrrrr}
\hline \multirow{2}{*}{ Jenis nutrien } & \multicolumn{2}{c}{$\begin{array}{c}\text { Konsumsi nutrien sebelum } \\
\text { suplementasi }(\mathrm{kg})\end{array}$} & \multicolumn{2}{c}{$\begin{array}{c}\text { Konsumsi nutrien sesudah } \\
\text { suplementasi }(\mathrm{kg})\end{array}$} \\
\cline { 2 - 5 } & Jaya Abadi & Progo Jaya & Jaya Abadi & Progo Jaya \\
\hline BK & $14,27 \pm 5,27$ & $14,36 \pm 3,52$ & $12,90 \pm 5,49$ & $16,92 \pm 3,68$ \\
BO & $11,94 \pm 4,55$ & $12,31 \pm 3,43$ & $10,27 \pm 4,43$ & $14,13 \pm 3,05$ \\
PK & $1,32 \pm 0,56$ & $0,96 \pm 0,25$ & $1,48 \pm 0,49$ & $1,20 \pm 0,27$ \\
SK & $3,19 \pm 1,17$ & $3,30 \pm 0,83$ & $2,33 \pm 1,33$ & $3,71 \pm 0,82$ \\
TDN & $6,43 \pm 2,34$ & $7,08 \pm 1,77$ & $5,58 \pm 2,61$ & $8.67 \pm 1,83$ \\
\hline
\end{tabular}

Konsumsi nutrien baik,kecuali PK, BK, BO, SK dan TDN pada kelompok Jaya Abadi mengalami penurunan pada saat dilakukan suplementasi dedak padi. Hal ini disebabkan terjadinya penurunan jumlah pemberian pakan. Peternak tidak melakukan pemberian pakan sesuai kebutuhan ternak tetapi berdasarkan ketersediaan pakan, sehingga pada saat ketersediaan pakan melimpah maka akan diberikan pakan dalam jumlah yang banyak sebaliknya pada saat terjadi kekurangan pakan peternak akan memberikan pakan dalam jumlah seadanya. Usaha ternak sapi potong merupakan usaha sambilan sehingga usaha untuk memberikan input pada ternak tidak dilakukan secara maksimal.

Sebaliknya pada kelompok ternak Progo Jaya, konsumsi nutrien baik BK, BO, PK, SK dan TDN mengalami peningkatan selama dilakukan suplementasi dedak padi. Hal ini diduga terjadi peningkatan kecernaan pakan akibat suplementasi (Mcdonald et al. 2010).

\section{Kandungan nutrien ransum, pertambahan berat badan harian dan profil darah}

Kandungan nutrien ransum, pertambahan berat badan harian dan profil darah sapi induk ditampilkan pada sebelum dan saat dilakukan suplementasi dicantumkan pada Tabel 5.

Tabel 5. Kandungan nutrien ransum, $\mathrm{PBBH}$ dan profil darah sebelum dan saat dilakukan suplementasi

\begin{tabular}{lcccc}
\hline \multirow{2}{*}{ Jenis nutrien } & \multicolumn{2}{c}{$\begin{array}{c}\text { Kandungan nutrien ransum } \\
\text { sebelum suplementasi }(\mathrm{kg})\end{array}$} & \multicolumn{2}{c}{$\begin{array}{c}\text { Kandungan nutrien ransum } \\
\text { sesudah suplementasi (kg) }\end{array}$} \\
\cline { 2 - 5 } & Jaya Abadi & Progo Jaya & Jaya Abadi & Progo Jaya \\
\hline BO (\% BK) & 81,17 & 86,17 & 79,59 & 83,70 \\
PK (\% BK) & 8,99 & 6,45 & 11,47 & 7,00 \\
SK (\% BK) & 22,61 & 23,22 & 18,06 & 22,01 \\
TDN (\% BK) & 42,92 & 48,97 & 43,26 & 51,09 \\
PBBH (kg/ekor/hari) & $0,15 \pm 0,06$ & $0,22 \pm 0,12$ & $0,25 \pm 0,33$ & $0,38 \pm 0,81$ \\
Glukosa (mg/dl) & 19,88 & 22,36 & 20.97 & 23,55 \\
Plasma urea darah (mg/dl) & 16,65 & 15,16 & 17,57 & 15,87 \\
\hline
\end{tabular}

Suplementasi dedak padi di kelompok ternak Jaya Abadi meningkatkan kandungan PK (8,99\% menjadi 11,47\%) dan menurunkan kandungan SK (22,61\% menjadi $18,06 \%)$ dan BO (81,17 menjadi 79,59), sedangkan kandungan TDN sedikit mengalami kenaikan (42,92\% menjadi 43,26\%). Kandungan TDN pada ransum di kelompok Jaya Abadi sangat rendah sehingga menyebabkan kenaikan berat badan yang tidak terlalu tinggi yaitu 
$0,15 \pm 0,06 \mathrm{~kg} / \mathrm{ekor} / \mathrm{hari}$ (sebelum dilakukan suplementasi) dan $0,25 \pm 0,33 \mathrm{~kg} / \mathrm{ekor} / \mathrm{hari}$ (sesudah dilakukan suplementasi).

Suplementasi dedak padi di kelompok ternak Progo Jaya sedikit meningkatkan kandungan PK (6,45\% menjadi 7,00\%) dan menurunkan kandungan SK (23,22\% menjadi 22,01\%), kandungan TDN sedikit mengalami kenaikan (48,97\% menjadi 51,09\%). Capaian pertambahan berat badan harian di kelompok Progo Jaya lebih tinggi yaitu $0,22 \pm 0,12 \mathrm{~kg} / \mathrm{ekor} / \mathrm{hari}$ (sebelum dilakukan suplementasi) menjadi $0,38 \pm 0,81 \mathrm{~kg} / \mathrm{ekor} / \mathrm{hari}$ (sesudah dilakukan suplementasi).

Suplementasi dedak padi menyebabkan peningkatan kadar glukosa darah dan menurunkan plasma urea darah di kelompok Jaya Abadi maupun kelompok Progo Jaya. Glukosa merupakan gula sederhana yang akan diubah menjadi energi. Pada sapi induk energi merupakan nutrisi primer untuk tercapainya performa reproduksi optimal (Mass. 1987). Kecukupan energi akan memperpendek masa anoestrus post partus, meningkatkan angka konsepsi dan kebuntingan.

Penurunan plasma urea darah pada sapi induk menunjukkan keseimbangan pemanfaatan protein dan energi di dalam rumen. Konsentrasi plasma urea darah yang tinggi menunjukkan hasil degradasi protein di dalam rumen mempunyai efisiensi yang rendah pada pemanfaatan amonia di dalam rumen untuk pertumbuhan mikroba rumen (Chumpawadee et al. 2006) selain itu ketidakseimbangan pemanfaatan amonia dapat menyebabkan menurunnya fertilitas pada sapi induk (Sinclair et al. 2000).

\section{KESIMPULAN}

Suplementasi dedak padi pada sapi induk dengan pakan berbasis limbah tanaman pangan diperlukan unttuk meningkatkan nilai biologis pakan karena dapat meningkatkan kandungan protein kasar, meningkatkan energi dalam bentuk TDN, pertambahan berat badan harian dan glukosa. Disarankan pada pemberian pakan berbasis limbah tanaman pangan perlu dilakukan suplementasi bahan pakan sumber protein dan sumber energi agar dapat mengoptimalkan penggunaan limbah tanaman pangan berupa sumber serat.

\section{UCAPAN TERIMA KASIH}

Penulis mengucapkan terima kasih kepada kepala Ibu Retno Wandansari, S.Pt., M.P selaku kepala Sub Dinas Peternakan Kota Probolinggo yang telah memberikan ijin untuk melakukan penelitian di kelompok ternak binaan Sub Dinas Peternakan Kota Probolinggo, Ibu Dyah Tuwi ramsiati dan Ibu Wahyuni Indah Wulan Sari yang telah membantu pengambilan darah pada sapi potong.

\section{DAFTAR PUSTAKA}

Anonimous. 2007. Prospek dan arah pengembangan agribisnis sapi. Jakarta (Indonesia): Badan Penelitian dan Pengembangan Pertanian.

BPS Kota Probolinggo. 2015. Kota Probolinggo dalam Angka tahun 2015. Probolinggo (Indonesia): Badan Pusat Statistik Kota Probolinggo.

Chumpawadee S, Sommart T, Vongpralup, Pattarajinda V. 2006. Effects of synchronizing the rate of dietary energy and nitrogen release on ruminal fermentation, microbial protein synthesis, blood urea nitrogen and nutrient digestibility in beef cattle. Asian Aust J Anim Sci. 19:181-188. 
Cooke RF, Arthington JD, Staples CR, Thatcher WW, Lamb GC. 2007. Effects of supplement type on performance, reproductive, and physiological responses of Brahman-Crossbred females. J Anim Sci. 85:2564-2574.

Hartadi H, Reksohadiprodjo S, Tillman AD. 1997. Tabel komposisi pakan untuk Indonesia. Edisi keempat. Yogyakarta (Indonesia): UGM Press.

Mass J. 1987. Relationship between nutrition and reproduction in beef cattle. Vet Clin N Am Food Anim Pract. 3:633-646.

McDonald P, Edward RA, Greenhalgh JFD, Morgan CA. 2010. Animal nutrition. 6th ed. New York (USA): Longman Scientific and Technical Copublished in United States with John Wiley \& Sons Inc.

Martawidjaja M. 2003. Pemanfaatan jerami padi sebagai pengganti rumput untuk ternak ruminansia kecil. Wartazoa. 13:119-127.

Preston TR, Leng RA. 1987. Matching ruminant production system with available resources in the tropic and sub tropics. Armidale (Australia): Penambul Book.

Sinclair KD, Sinclair LA, Robinson JJ. 2000. Nitrogen metabolism and fertility in cattle: I. Adaptive changes in intake and metabolism to diets differing in their rate of energy and nitrogen release in the rumen. J. Anim. Sci. 78:2659-2669

Simatupang PD, Hadi PU. 2004. Daya saing usaha peternakan menuju 2020. Wartazoa. 14:45-57.

Umiyasih U, Wina E. 2008. Pengolahan dan nilai nutrisi limbah tanaman jagung sebagai pakan ternak ruminansia. Wartazoa 18:127-136.

Utomo R. 2004. Review hasil-hasil penelitian pakan sapi potong. Wartazoa 14:116-124. 